Contemporary Research in Education and English Language Teaching

ISSN: 2641-0230

Vol. 3, No. 2, pp. 31-40.

2021

Publisher: Learning Gate

DOI: 10.33094/26410230.2021.32.31.40

(C) 2021 by the authors; licensee Learning Gate

\title{
Chinese Undergraduates' Performance in HOTS and LOTS EFL Reading Comprehension for Different Reading Materials According to Gender
}

\author{
Li Lingfeng \\ PhD Student, Faculty of Education and Liberal Studies, City University, Malaysia, Petaling Jaya, Selangor, Malaysia. \\ Email:2084575@gq.com Tel:86-13907191637 \\ Subadrah Madhawa Nair* \\ Lecturer, Education and Liberal Studies, City University, Malaysia, Petaling Jaya, Selangor, Malaysia. \\ Email:subadrah.nair@city.edu.my Tel:016-4982439 (*Corresponding Author)
}

Received: 3 September 2021; Revised: 30 September 2021; Accepted: 15 October 2021; Published: 1 November 2021

\begin{abstract}
Many studies indicate that Chinese undergraduates face problems in their HOTS comprehension. The objective of this study is to investigate Chinese EFL undergraduates' HOST and LOTS reading comprehension according to gender. A descriptive research design was employed in this quantitative study. The researchers used an English reading comprehension test involving 5 different materials (education, economy, entertainment, technology and natural disaster) as the research instrument. Each material consists of 3 LOTS questions and 2 HOTS questions. All the comprehension questions were multiple choice in nature. The sample of the study consists of 411 second year undergraduate students (261 females and 150 males) from a university in Hunan Province, China. SPSS Program for Windows version 25 was used to analyze the data (Independent samples $t$-test). The findings of this current study indicated that the female students performed significantly better than their male counterparts for both LOTS and HOTS comprehension questions. The female students also outperformed their male students in their overall score for comprehension. As such, these results clearly revealed that female undergraduates performed significantly better than the males in their EFL reading comprehension skills. However, this research only involves participants from one university; as a result, future research should include a larger sample from different provinces in China to get a better insight of students' performance in EFL comprehension.
\end{abstract}

Keywords: HOTS, LOTS, EFL, Reading comprehension, Undergraduate, Gender, China, Reading material.

\section{Introduction}

In China, English as a foreign language has gradually become more and more important in China today (Hu, 2009). As an article from 2010 China Daily reported, one third population in China are learning English today. English is taught as a compulsory subject from Grade 3 to university level while reading comprehension being regarded as a fundamental part in English acquisition. In public schools the Chinese English teachers give great importance to students' EFL reading comprehension. The reading comprehension skill is so important that "all the English classes are about reading comprehension." (Lin, 2019). Meanwhile, the EFL reading comprehension occupies an essential status in all the key English examinations of the whole Chinese educational system such as the Senior High School Entrance Examination, the National College Entrance Exams, the Senior High School Entrance Examination, the National College Entrance Exams, the College English Test-Brand Four (CET 4) and the College English Test-Brand six (CET 6).

Lately, the Outline of National Medium and Long-term Education Reform and Development Plan (2010-2020) in China called for the improvement of EFL students' ability of learning, practicing and

(C) 2021 by the authors; licensee Learning Gate, UK 
creativity, which proposed a higher requirement for EFL students' higher order thinking skills (HOTS) according to the revised Bloom's taxonomy (Anderson \& Krathwohl, 2001). The College English Teaching Guidelines of 2017 issued by Chinese educational ministry requires undergraduates not only to understand familiar reading materials, but also to analyze and creatively comprehend the reading materials using appropriate reading methods. The basic level of the Chinese Educational Ministry (2017) needs English teachers train undergraduates in Lower Order Thinking skills (LOTS) while the at the higher level demands a good training in answering the HOTS questions. Meanwhile, HOTS questions are more challenging for Chinese EFL undergraduates compared with LOTS questions as it requires a critical thinking.

Although undergraduates' performance in HOTS and LOTS reading comprehension are important in China, there is a research gap in studying the HOTS and LOTS reading comprehension as shown in the literature review. When considering HOTS and LOTS reading comprehension for different reading materials according to gender, studies are even more limited. With a view to filling these research gaps, this study aimed to compare the performance of male and female undergraduates' reading comprehension for HOTS and LOTS questions.

\section{Literature Review}

Reading comprehension requires readers to understand and interpret the content of a presented reading material (Bell, 1991). During the reading process, readers always experience "the process of decoding and constructing meaning through interaction and involvement with a written text" (Abu, 2010). The comprehension of a reading material is not just a verbal processing of meaning construction as it requires students to recall details, find facts, gain the main idea, make inferences, draw conclusions, make prediction, evaluation and creation on the base of presented materials (Bell, 1991).

Zintz (1978) concluded three comprehension skills, namely, literal comprehension skills, interpretive skills and critical reading ability. With reference to the revised Bloom's taxonomy (Anderson \& Krathwohl, 2001), literal comprehension may correspond to the LOTS comprehension during which readers can just memorize the information. At the interpretive level, readers need to combine prior knowledge with their literal understanding to make inferences and go deeper beyond literal comprehension (Nourdad, Masoudi, \& Rahimali, 2018). The applied level was discussed by Nair, Zhang, and Wider (2019) as concerning about the critical reading ability which needs critical evaluation as well as elevating the thinking at a more critical and analyzing level. The development of reading comprehension skills are in correspondence with Bloom's taxonomy (Anderson \& Krathwohl, 2001) as the higher level of reading skills can match with the HOTS (analyzing, evaluating, and creating).

Many studies (Chou, 2011; Yousef, Karimi, \& Janfeshan, 2014) before has shown that students face problems in EFL reading comprehension especially in HOTS reading comprehension just as Fisher (2005) pointed out: "students find it difficult to read between the lines to understand the passages and the intentions of the writer". Compared with LOTS reading comprehension, HOTS reading comprehension requires more critical thinking for analyzing, evaluating and creating instead of understanding the passages at the literal level. Previous findings of Alfaki (2014); Khan and Inamullah (2011) indicated that students are less trained in answering HOTS reading comprehension questions and they tend to perform better in LOTS reading comprehension.

\subsection{Theories of Reading Comprehension}

Considering theories of Reading Comprehension, there are several well-known theories, namely, the Bottom-up Theory, Top-Down Theory, Interactive Theory, and Schema Theory.

The bottom-up models emphasis on the text while the top-down models focus on readers' background knowledge. Reading in a bottom-up model is viewed as a matter of decoding a series of written symbols (Nunan, 1991) which starts with smallest linguistic units and other low-to-high language levels. Differently, the top-down model generally refers to the selective and purposeful reading 
process which is actively controlled by the readers (Grabe, 2009). In the top-down reading process, readers leaps towards meaning (Goodman, 1976) with the help of their background knowledge.

To achieve more balance between bottom-up and top-down processing models, Interactive reading model appeared as the alternating or simultaneous use of the first two reading models. Interactive reading model is a joint mechanism of the visual processing from written text and the non-visual from the existing knowledge or cultural background knowledge in the brain. Interactive reading is a process between the reader and the text as well as the reader and the author, with a focus on reader's initiative and reading fluency (Al-Yousef, 2007). Interaction has three levels: the interaction between the two processing including bottom-up and top-down; the interaction among skills at different levels; and the interaction between readers' prior knowledge and the knowledge of the given passages (An, 2013).

Schema was introduced by Rumelhart (1980); Carrell (1981) and Hudson (1982) who have realized the significance of background knowledge in reading comprehension. Schema theory is an explanation of how readers use prior knowledge to comprehend and learn from text (Rumelhart, 1980). The Schema Theory explains that the stored knowledge of readers is to be recollected from their long-term memory (McVee, Dunsmore, \& Gavelek, 2005) on which the reader based to give meaning to the text while reading (Brown, 2001).

\subsection{Studies Related to Comprehension According to Gender}

Gender difference is reflected in language as Brantmeier (2001); Brantmeier (2003) stressed that female and female exhibit different language patterns. Since male students and female students' engagement in English reading is different influenced by their schemata, knowledge and experience, gender factor is important while studying reading (Brantmeier, 2003). There are several studies interesting in the correlation between gender factors and reading comprehension in learning a foreign language (Jalilehvand \& Samuel, 2014). A substantial results before has showed that there is gender differences in readers' attitudes, reading motivation and adoption of reading strategies which may in turn influence their reading achievement (Logan \& Johnston, 2009; Wang \& Guthrie, 2004).

Mullis, Martin, Gonzalez, and Kennedy (2003); Mullis, Martin, Kennedy, and Foy (2007) international studies included 40 countries found that the in every participating country, girls outperformed boys. This results was in line with findings of Ming Chui and McBride-Chang (2006) whose study included 15 year old adolescence from 43 countries. Gender differences seem favor females more than males regardless of how the reading instruction is used (Johnston, Watson, \& Logan, 2009). Many researchers before has shown that female students have higher achievement in reading comprehension compared with their male counterparts (Arellano \& Dolores, 2013). As Zhenhui (2005) stressed, female students have better language learning skills.

A cross-gender comparison made by Manizheh (2016) revealed that female students use metacognitive reading strategies more often than male students. According to Manizheh' findings, female students are more skillful in applying the reading strategies, especially in using strategies for solving reading problems. Compared with female students, male students are more likely to face languagerelated problems (Halpern, 2000).

Females performed better in answering HOTS questions is partly because they are good at guessing meaning and identifying main ideas (Yazdanpanah, 2007). Meanwhile, compared with male students, female students are more likely to have more frequency of reading and more active attitude towards reading and school (Logan \& Johnston, 2009). Saidi (2012) study also showed that females are more hardworking than males. Ala and Mohsen (2017) further demonstrated that females significantly outperformed male in critical reading while there is no significant difference between males and females on three levels of reading comprehension, namely, literal, inferential and appreciative.

Realizing that male students are in a disadvantage position in reading comprehension, some researchers (Logan \& Johnston, 2010) began to search ways to help male students and find out their specific advantages in reading comprehension. Researchers found that the reading material influences students' performance as male students perform better in answering multiple-choice reading questions 
related to topics of laser thermometers, volcanoes, cars and football players (Bügel \& Buunk, 1996). Male students also tend to outperform female at document materials (OECD, 2016). At the same time, males rather than females are more favored in terms of logical inference (Pae, 2004).

Besides, previous researchers of L1 and L2 investigated the correlation between the reading content and the gender of the of the reader. Bray and Barron (2004) found that interest has a stronger impact on girls' test performance. Seyedjamal (2014) further found that females outperformed males in all text content in the university setting. As stressed by Oakhill and Petrides (2007), compared with boys, girls' performance was relatively little affected by text content so that girls tent to continue reading with lower-interesting text. As such, it is meaningful for the current research to follow the previous researches in focusing on the gender factor as well as the types of reading materials in studying HOTS and LOTS reading comprehension among Chinese undergraduates.

\section{Methodology}

In this study, the researcher utilized a descriptive research design using the quantitative data. The sample are 411 second year undergraduates (261 females and 150 males) from a university in Hunan, China. These students learn English as a foreign language and they are selected using purposive sampling from 5 faculties.

A reading comprehension test which involves 5 different passages, namely economy, entertainment, education, technology and natural disaster. Each passage (around 500 words for each text) was used as an instrument to gauge students level of comprehension in HOTS and LOTS questions. For each passage there are 2 HOTS and 3 LOTS multiple choice questions. All their scores for LOTS and HOTS question are changed onto percentages before the analysis.

The researcher also did a pilot test among 40 students to obtain the reliability of the instrument. Based on the results of the pilot study, some questions are modified and the testing hour of the actual test is decided to be two hours. The reliability calculator created by Del Siegle showed that the instrument is highly reliable $(\mathrm{KR} 21=0.70, \mathrm{KR} 20=0.75$, Cronbach's Alpha $=0.75)$.

RQ 1: Is there a significant difference in students' performance in reading comprehension of LOTS questions according to gender?

Table-1.

Comparison of students' mean scores in English reading comprehension of LOTS questions according to gender.

\begin{tabular}{c|c|c|c|c|c|c|c}
\hline Group & $\mathbf{N}$ & Mean & Std. Deviation & Mean Difference & t-value & df & p-value \\
\hline Male & 150 & 42.80 & 17.53 & -11.73 & -6.27 & 409 & 0.000 \\
\hline Female & 261 & 54.53 & 18.64 & & & \\
\hline
\end{tabular}

\section{Data Analysis and Results}

The findings in Table 1 indicated the female undergraduates' LOTS scores in EFL reading comprehension is much higher $(\mathrm{Mean}=54.3$; $\mathrm{SD}=18.64)$ than the male undergraduates (Mean=42.80; $\mathrm{SD}=17.53)$. Results of the independent samples t- test clearly show that the female undergraduates performed significantly better compared with the males in LOTS EFL reading comprehension $(\mathrm{t}=-6.27$; $\mathrm{df}=409$; Mean difference $=-11.73 ; \mathrm{p}=.000$ ).

RQ 2: Is there a significant difference in students' performance in reading comprehension of HOTS questions according to gender?

Table-2.

Comparison of students' mean scores in English reading comprehension of HOTS questions according to gender.

\begin{tabular}{c|c|c|c|c|c|c|c}
\hline Group & $\mathbf{N}$ & Mean & Std. Deviation & Mean Difference & t-value & df & p-value \\
\hline Male & 150 & 38.26 & 19.89 & -10.20 & -4.69 & 409 & 0.000 \\
\hline Female & 261 & 48.46 & 21.90 & & & & \\
\hline
\end{tabular}

Note: Level of significance at $\mathrm{p}<0.05$. 
The findings exhibited in Table 2 showed that the female undergraduates' HOTS scores in EFL reading comprehension is higher (Mean $=48.46$; $\mathrm{SD}=21.90$ ) than the male undergraduates (Mean=38.26; $\mathrm{SD}=19.89$ ). The results of the independent sample t- test showed that the female undergraduates performed significantly better compared with their male counterparts in answering HOTS EFL reading comprehension questions ( $\mathrm{t}=-4.69 ; \mathrm{df}=409$; Mean difference $=-10.20 ; \mathrm{p}=.000$ ).

RQ 3: Is there a significant difference in students' overall performance in reading comprehension according to gender?

Table-3.

Comparison of students' Overall mean scores in English reading comprehension according to gender.

\begin{tabular}{c|c|c|c|c|c|c|c}
\hline Group & $\mathbf{N}$ & Mean & Std. Deviation & Mean Difference & t-value & df & p-value \\
\hline Male & 150 & 40.98 & 16.32 & -11.12 & -6.24 & 409 & 0.000 \\
\hline Female & 261 & 52.10 & 17.94 & & & \\
\hline
\end{tabular}

The findings in Table 3 showed that the female students' overall mean scores in EFL reading comprehension is much higher (Mean=52.10, $\mathrm{SD}=17.94$ ) than their male counterparts (Mean=40.98, $\mathrm{SD}=16.32)$. The results of the Independent samples t-test indicated that the female students performed significantly better compared with the male students $(\mathrm{t}=-6.24 ; \mathrm{df}=409 ;$ Mean difference $=-11.12 ; \mathrm{p}=.000)$. These findings indicated that there is a significant difference in students' performance in term of answering overall EFL reading comprehension questions.

RQ 4: Is there a significant difference in students' performance in answering HOTS questions for different types of reading materials according to gender?

Table-4.

Comparison of students' mean scores in answering HOTS questions for different types of reading materials according to gender.

\begin{tabular}{|c|c|c|c|c|c|c|c|c|}
\hline $\begin{array}{l}\text { Reading } \\
\text { Material }\end{array}$ & Group & $\mathbf{N}$ & Mean & Std. Deviation & $\begin{array}{c}\text { Mean } \\
\text { Difference }\end{array}$ & t-value & df & p-value \\
\hline \multirow[t]{2}{*}{ Economy } & Male & 150 & 40.33 & 36.95 & \multirow[t]{2}{*}{-14.65} & \multirow[t]{2}{*}{-3.95} & \multirow[t]{2}{*}{409} & \multirow[t]{2}{*}{0.000} \\
\hline & Female & 261 & 54.98 & 35.82 & & & & \\
\hline \multirow[t]{2}{*}{ Education } & Male & 150 & 34.00 & 34.91 & \multirow[t]{2}{*}{-5.46} & \multirow[t]{2}{*}{-1.53} & \multirow[t]{2}{*}{409} & \multirow[t]{2}{*}{0.128} \\
\hline & Female & 261 & 39.46 & 35.00 & & & & \\
\hline \multirow{2}{*}{$\begin{array}{c}\text { Entertainme } \\
\text { nt }\end{array}$} & Male & 150 & 27.67 & 32.53 & \multirow[t]{2}{*}{-15.25} & \multirow[t]{2}{*}{-4.01} & \multirow[t]{2}{*}{409} & \multirow[t]{2}{*}{0.000} \\
\hline & Female & 261 & 42.91 & 39.44 & & & & \\
\hline \multirow{2}{*}{$\begin{array}{l}\text { Natural } \\
\text { disaster }\end{array}$} & Male & 150 & 33.67 & 35.94 & \multirow[t]{2}{*}{-6.75} & \multirow[t]{2}{*}{-1.76} & \multirow[t]{2}{*}{409} & \multirow[t]{2}{*}{0.079} \\
\hline & Female & 261 & 40.42 & 38.38 & & & & \\
\hline \multirow[t]{2}{*}{ Technology } & Male & 150 & 55.67 & 37.33 & \multirow[t]{2}{*}{-8.89} & \multirow[t]{2}{*}{-2.51} & \multirow[t]{2}{*}{409} & \multirow[t]{2}{*}{0.012} \\
\hline & Female & 261 & 64.56 & 32.80 & & & & \\
\hline
\end{tabular}

Note: Level of significance at $\mathrm{p}<0.05$.

The findings in Table 4 indicated the female undergraduates' HOTS scores in answering the reading material of Economy is much higher (Mean=54.98; $\mathrm{SD}=35.82$ ) than the male undergraduates (Mean=40.33; $\mathrm{SD}=36.95$ ). Results of the independent samples t- test clearly show that the female undergraduates performed significantly better compared with the males in their reading comprehension for text of Economy ( $\mathrm{t}=-3.95 ; \mathrm{df}=409$; Mean difference $=-14.65 ; \mathrm{p}=.000)$.

The results also clearly indicate that for the text of Entertainment, the female undergraduates' HOTS scores is also much higher (Mean=42.91; $\mathrm{SD}=39.44$ ) than the male undergraduates (Mean=27.67; $\mathrm{SD}=32.53)$. Results of the independent samples t-test also show that the female undergraduates 
performed significantly better compared with the males $(\mathrm{t}=-4.01$; $\mathrm{df}=409$; Mean difference $=-15.25$; $\mathrm{p}=.000)$.

In terms of text on Technology, the female undergraduates' HOTS scores is also much higher (Mean=64.56; $\mathrm{SD}=32.80$ ) than the male undergraduates (Mean=55.67; $\mathrm{SD}=37.33$ ). However, results of the independent samples t- test show that there is no significant difference between male and female undergraduates in their comprehension for text on Technology $(t=-8.89$; $\mathrm{df}=409$; Mean difference $=-$ $2.51 ; \mathrm{p}=.012)$.

The findings also revealed that there is no significant difference between male and female undergraduates in their comprehension for text on Education $(t=-1.53$; $\mathrm{df}=409$; Mean difference $=-5.46$; $\mathrm{p}=.128$ ). Similarly for the text on Natural disaster the difference between males and females is not significant $(\mathrm{t}=-1.76 ; \mathrm{df}=409$; Mean difference=-6.75; $\mathrm{p}=.079)$.

RQ 5: Is there a significant difference in students' performance in answering LOTS questions for different types of reading materials according to gender?

Table-5.

Comparison of students' mean scores in answering LOTS questions for different types of reading materials according to gender.

\begin{tabular}{|c|c|c|c|c|c|c|c|c|}
\hline $\begin{array}{c}\text { Types of reading } \\
\text { Material }\end{array}$ & Group & $\mathbf{N}$ & Mean & $\begin{array}{c}\text { Std. } \\
\text { Deviation }\end{array}$ & $\begin{array}{c}\text { Mean } \\
\text { Difference }\end{array}$ & t-value & df & $\begin{array}{c}\mathrm{p}- \\
\text { value }\end{array}$ \\
\hline \multirow{2}{*}{ Economy } & Male & 150 & 59.11 & 27.89 & \multirow[t]{2}{*}{-6.92} & \multirow[t]{2}{*}{-2.49} & \multirow[t]{2}{*}{409} & \multirow[t]{2}{*}{0.013} \\
\hline & Female & 261 & 66.03 & 26.71 & & & & \\
\hline \multirow[t]{2}{*}{ Education } & Male & 150 & 35.78 & 29.94 & \multirow[t]{2}{*}{-21.82} & \multirow[t]{2}{*}{-7.01} & \multirow[t]{2}{*}{409} & \multirow[t]{2}{*}{0.000} \\
\hline & Female & 261 & 57.60 & 30.64 & & & & \\
\hline \multirow[t]{2}{*}{ Entertainment } & Male & 150 & 18.45 & 21.69 & \multirow[t]{2}{*}{-10.16} & \multirow[t]{2}{*}{-4.01} & \multirow[t]{2}{*}{409} & \multirow[t]{2}{*}{0.000} \\
\hline & Female & 261 & 28.61 & 26.29 & & & & \\
\hline \multirow[t]{2}{*}{ Natural disaster } & Male & 150 & 42.67 & 31.16 & \multirow[t]{2}{*}{-15.70} & \multirow[t]{2}{*}{-4.87} & \multirow[t]{2}{*}{409} & \multirow[t]{2}{*}{0.000} \\
\hline & Female & 261 & 58.37 & 31.68 & & & & \\
\hline \multirow[t]{2}{*}{ Technology } & Male & 150 & 47.56 & 31.69 & \multirow[t]{2}{*}{-15.02} & \multirow[t]{2}{*}{-4.75} & \multirow[t]{2}{*}{409} & \multirow[t]{2}{*}{0.000} \\
\hline & Female & 261 & 62.58 & 30.39 & & & & \\
\hline
\end{tabular}

Note: Level of significance at $\mathrm{p}<0.05$.

The findings in Table 5 indicated the female undergraduates' LOTS scores in answering the reading material of Education is much higher (Mean $=57.60 ; \mathrm{SD}=30.64$ ) than the male undergraduates (Mean=35.78; $\mathrm{SD}=29.94$ ). Results of the independent samples t-test clearly show that the female undergraduates performed significantly better compared with the males in their reading comprehension for text of Education ( $\mathrm{t}=-7.01$; $\mathrm{df}=409$; Mean difference=-21.82; $\mathrm{p}=.000$ ).

The results also clearly indicate that for the text of Entertainment, the female undergraduates' LOTS scores is also much higher (Mean=28.61; $\mathrm{SD}=26.29$ ) than the male undergraduates (Mean=18.45; $\mathrm{SD}=21.69$ ). Results of the independent samples t-test also show that the female undergraduates performed significantly better compared with the males for text of Entertainment $(t=-4.01$; $d f=409$; Mean difference $=-10.16 ; \mathrm{p}=.000$ ).

In terms of text on Natural disaster, the female undergraduates' LOTS scores is also much higher (Mean=58.37; $\mathrm{SD}=31.68$ ) than the male undergraduates (Mean=42.67; $\mathrm{SD}=31.16$ ). The results of the independent samples t-test also show that there is a significant difference between male and female undergraduates in their comprehension for text on Natural disaster $(t=-4.87 ; \mathrm{df}=409$; Mean difference $=-$ $15.70 ; \mathrm{p}=.000$ ).

Similarly, the female undergraduates' LOTS scores in answering the reading material of Technology is much higher (Mean $=62.58 ; \mathrm{SD}=30.39$ ) than the male undergraduates (Mean=47.56; $\mathrm{SD}=31.69$ ). Results of the independent samples t-test clearly show that the female undergraduates 
performed significantly better compared with the males in their reading comprehension for text of Technology ( $\mathrm{t}=-4.75 ; \mathrm{df}=409$; Mean difference=-15.02; $\mathrm{p}=.000)$.

The findings also revealed that when answering LOTS comprehension for text on Economy, the female undergraduates performed better (Mean=66.03; $\mathrm{SD}=26.71$ ) than their male counterparts (Mean=59.11; $\mathrm{SD}=27.89$ ). However, findings from the independent samples t-test indicate that although females performed better compared with their male counterparts, their scores are not significantly higher $(\mathrm{t}=-2.49 ; \mathrm{df}=409$; Mean difference=-6.92; $\mathrm{p}=.013)$.

$\mathrm{RQ}$ 6: Is there a significant difference in students' overall performance in answering different types of reading materials according to gender?

Table-6.

Comparison of students' overall mean scores in answering different types of reading materials according to gender.

\begin{tabular}{|c|c|c|c|c|c|c|c|c|}
\hline $\begin{array}{l}\text { Reading } \\
\text { Material }\end{array}$ & Group & $\mathbf{N}$ & Mean & $\begin{array}{c}\text { Std. } \\
\text { Deviation }\end{array}$ & $\begin{array}{c}\text { Mean } \\
\text { Difference }\end{array}$ & t-value & df & p-value \\
\hline \multirow[t]{2}{*}{ Economy } & Male & 150 & 51.60 & 25.41 & \multirow[t]{2}{*}{-10.01} & \multirow[t]{2}{*}{-4.03} & \multirow[t]{2}{*}{409} & \multirow[t]{2}{*}{0.000} \\
\hline & Female & 261 & 61.60 & 23.51 & & & & \\
\hline \multirow[t]{2}{*}{ Education } & Male & 150 & 35.07 & 25.48 & \multirow[t]{2}{*}{-15.28} & \multirow[t]{2}{*}{-5.89} & \multirow[t]{2}{*}{409} & \multirow[t]{2}{*}{0.000} \\
\hline & Female & 261 & 50.34 & 25.21 & & & & \\
\hline \multirow[t]{2}{*}{ Entertainment } & Male & 150 & 28.40 & 22.74 & \multirow[t]{2}{*}{-5.62} & \multirow[t]{2}{*}{-2.21} & \multirow[t]{2}{*}{409} & \multirow[t]{2}{*}{0.000} \\
\hline & Female & 261 & 34.02 & 26.04 & & & & \\
\hline \multirow{2}{*}{$\begin{array}{l}\text { Natural } \\
\text { disaster }\end{array}$} & Male & 150 & 39.07 & 26.76 & \multirow[t]{2}{*}{-12.12} & \multirow[t]{2}{*}{-4.21} & \multirow[t]{2}{*}{409} & \multirow[t]{2}{*}{0.000} \\
\hline & Female & 261 & 51.19 & 28.83 & & & & \\
\hline \multirow[t]{2}{*}{ Technology } & Male & 150 & 50.80 & 27.67 & \multirow[t]{2}{*}{-12.57} & \multirow[t]{2}{*}{-4.76} & \multirow[t]{2}{*}{409} & \multirow[t]{2}{*}{0.000} \\
\hline & Female & 261 & 63.37 & 24.64 & & & & \\
\hline
\end{tabular}

Note: Level of significance at $\mathrm{p}<0.05$.

The findings in Table 6 indicated that for reading material of Economy the mean score of female undergraduates is higher (Mean=61.60; $\mathrm{SD}=23.51$ ) than the male undergraduates than the male undergraduates (Mean=51.60; $\mathrm{SD}=25.41$ ). Results of the Independent samples t- test clearly show that the female undergraduates performed significantly better compared with the males $(t=-4.03 ; \mathrm{df}=409$; Mean difference=-10.01; $\mathrm{p}=.000$ ).

Female undergraduates' mean score in answering the reading material of Education is also much higher (Mean=50.34; $\mathrm{SD}=25.21$ ) than the male undergraduates (Mean=35.07; $\mathrm{SD}=25.48$ ). Results of the independent samples t- test clearly reveal that the female undergraduates performed significantly better compared with the males in reading comprehension for text of Education $(t=-5.89$; $\mathrm{d}=409$; Mean difference $=-15.28 ; \mathrm{p}=.000$ ).

Meanwhile, female undergraduates has a much higher mean score in answering the reading text of Entertainment (Mean=34.02; $\mathrm{SD}=26.04$ ) than their male counterparts (Mean=28.40; $\mathrm{SD}=22.74$ ). Results of the independent samples $t$ - test indicate that the female undergraduates performed significantly better compared with the males in reading comprehension for text of Entertainment $(t=-$ 2.2 1; $\mathrm{df}=409$; Mean difference $=-5.62 ; \mathrm{p}=.000)$.

The situation is similar when considering undergraduates' performance of answering the reading material of Natural disaster. Female undergraduates' overall score in answering the reading material of Natural disaster is much higher (Mean=51.19; $\mathrm{SD}=28.83$ ) than the male undergraduates (Mean=39.07; $\mathrm{SD}=26.76)$. Results of the independent samples t- test clearly show that the female undergraduates performed significantly better compared with the males in in reading comprehension for text of Natural disaster $(\mathrm{t}=-4.21 ; \mathrm{df}=409$; Mean difference $=-12.12 ; \mathrm{p}=.000)$. 
In term of answering the reading material of Technology, female undergraduates' overall score is much higher (Mean=63.37; $\mathrm{SD}=24.64)$ than the male undergraduates (Mean=50.80; $\mathrm{SD}=27.67)$. Results of the independent samples t- test clearly show that the female undergraduates performed significantly better compared with the males in comprehending text of Technology $(\mathrm{t}=-4.76$; $\mathrm{df}=409$; Mean difference $=-12.57 ; \mathrm{p}=.000$ ).

\section{Discussions}

The findings in the current study support findings of Arellano and Dolores (2013) which showed that female students find it easier to answer LOTS questions because they have better skills than male students in getting information. Findings of Table 2 clearly answered RQ 2 that there is a significant difference in students' performance when they answer HOTS reading comprehension questions. The findings in the current study is in line with findings by Arellano and Dolores (2013) and Yazdanpanah (2007) which indicated that female students have higher achievements in reading comprehension especially in answering HOTS questions due to their better language learning skills (Zhenhui, 2005). Consistent with findings of Arellano and Dolores (2013); Mullis et al. (2003); Mullis et al. (2007); Ming Chui and McBride-Chang (2006) this study also revealed that female students performed better in answering reading comprehension questions. Meanwhile, these findings clearly answered RQ 4 that there is a difference in students' HOTS reading performance in different types of reading materials according to gender. Female students performed better especially in answering the reading materials on Economy and Entertainment. These results are consistent with findings of Ming Chui and McBrideChang (2006) which showed that girls performed better than boys in reading comprehension. Study by Halpern (2000) also stressed that language-related problems are more common in boys compared with girls. In addition, Bray and Barron (2004) found that there is a stronger positive relationship between topic interest and comprehension performance for girls compared with boys. They opined that reading uninterested topics, girls are more likely to persist while boys tend to give up. Moreover, these results clearly answered RQ 5 that there is a difference in students' LOTS reading performance related with different types of reading materials according to gender. Female students performed especially better in answering the reading material of Education, Entertainment, Natural disaster and Technology. This result further proved that females performed better on humanities-related topics (Brantmeier, 2001). Maybe this is because females performed better on learning skills relevant to the course grade (Ala \& Mohsen, 2017). The females' higher score may also due to their continuous persistence with reading even with texts of low-interest (Oakhill \& Petrides, 2007). In terms of RQ 6, the results revealed that there is a significant difference in students' overall performance in different types of reading materials (Economy, Education, Entertainment, Natural disaster and Technology) according to gender. The findings of the current study is parallel with results showed by Brantmeier (2001); Brantmeier (2003) and Seyedjamal (2014) which indicated that the females performed better on familiar text. As stressed by Saidi (2012) females use more strategies including memory strategies, cognitive and meta-cognitive strategies, as well as compensation strategies than males while learning. As such, the females outperform the males in their comprehension of all the reading materials.

\section{Conclusions, Implications and Recommendations}

According to the results of the quantitative data, the mean scores of the Chinese female undergraduates were higher than their male counterparts. The analysis indicated that the Chinese female undergraduates performed significantly better than the male undergraduates in answering HOTS, LOTS and Overall EFL reading comprehension questions. When dealing with the reading material of Economy, Education, Entertainment, Natural disaster and Technology, the female undergraduates also performed significantly better then their male counterparts.

These finds in the current study is in consistent with the findings of researchers like Arellano and Dolores (2013); Yazdanpanah (2007). This study also supported Bloom's Taxonomy which separated students' thinking skills into different levels arranged from simple to complex, that is from LOTS and 
HOTS. Compared with the LOTS, HOTS is more difficult for students to master which is in line with the findings of this current study. In terms of pedagogical implication, the Chinese EFL teachers should try to find better strategies to improve students' LOTS and HOTS comprehension.

Meanwhile, the results of the current study is in line with the findings of OECD (2016) and Pae (2004) which claimed that female students and male students performed differently when answering different types of reading materials. It is necessary for Chinese EFL teachers to take the reading materials into consideration when practice students' reading comprehension.

This study has many limitations. The first limitation relates to the reading material as there are only 5 types of reading passages used in this study (economy, entertainment, education, technology and natural disaster). As such the results of this study cannot be generalized to other types of reading comprehension such as sports, science, advertisement, history and so on. The second limitation is the sample which only consists of second year students from one university with limited number (411). Therefore, the findings cannot generalize to the whole country or different samples. The third limitation is that this study only used multiple-choice questions. As such, the findings can only generalized to the same type of EFL reading comprehension using multiple-choice questions.

\section{References}

Abu, S. (2010). The effectiveness of a suggested program based on prior knowledge to develop eighth graders' English Reading Comprehension Skills. MA Thesis Islamic University of Gaza.

Al-Yousef, H. (2007). An evaluation of the New Third Grade Intermediate English Course Book in Saudi Arabia. Master's Thesis. King Saud University, Saudi Arabia.

Ala, H. O., \& Mohsen, R. A. (2017). The relationship between gender and reading comprehension at college level. Journal of Basrah Research The Humanities Sciences, 42(6), 426-441. Available at: https://doi.org/10.33762/0694-042-006-019.

Alfaki, M. I. (2014). Sudan english language syllabus: Evaluating reading comprehension questions using Bloom's Taxonomy. International Journal of English Language Teaching, 2(3), 53-74.

An, S. Y. (2013). Schema theory in reading. Theory and Practice in Language Studies, 3(1), 130-134.

Anderson, L. W., \& Krathwohl, D. R. (2001). A taxonomy for learning, teaching and assessing: A revision of Bloom's Taxonomy of educational objectives: (pp. 67-68). New York: Longman.

Arellano, C., \& Dolores, M. (2013). Gender differences in reading comprehension achievement in English as a foreign language in compulsory secondary education. Tejuelo Didactics of Language and Literature, 17(1), 67-84.

Bell, N. (1991). Gestalt imagery: A critical factor in language comprehension. Annals of Dyslexia, 41(1), 246-260. Available at: https://doi.org/10.1007/bfo2648089.

Brantmeier, C. (2001). Second language reading research on passage content and gender: Challenges for the intermediate-level curriculum. Foreign Language Annals, 34(4), 325-333. Available at: https://doi.org/10.1111/j.19449720.2001.tbo2064.x.

Brantmeier, C. (2003). Does gender make a difference? Passage content and comprehension in second language reading. Reading in a Foreign Language, 15(1), 1-24.

Bray, B. G., \& Barron, S. (2004). Assessing reading comprehension: The effects of text-based interest, gender, and ability. Educational Assessment, 9(3-4), 107-128. Available at: https://doi.org/10.1207/s15326977ea0903\&4_2.

Brown, H. D. (2001). Teaching by principles: An interactive approach to language pedagogy. White Plains, NY: Addison Wesley Longman, Inc.

Bügel, K., \& Buunk, B. P. (1996). Sex differences in foreign language text comprehension: The role of interests and prior knowledge. The Modern Language Journal, 8O(1), 15-31. Available at: https://doi.org/10.2307/329055.

Carrell, P. L. (1981). Culture-specific schemata in L2 comprehension. Paper presented at the In Selected Papers From The Ninth Illinois TESOL/BE Annual Convention, The First Mid-West TESOL Conference, Richard Orem and John Haskell (Eds.). Chicago: Illinois TESOL/BE.

Chinese Educational Ministry. (2017). The college English teaching guidelines. Beijing: Higher Education Press.

Chou, P. (2011). The effects of vocabulary knowledge and background knowledge on reading comprehension of Taiwanese EFL students. Electronic Journal of Foreign Language Teaching, 8(1), 108-115.

Fisher, R. (2005). Teaching children to think. Cheltenham: Nelson.

Goodman, K. S. (1976). Reading: A psycholinguistic guessing game. In H. Singer and R. B. Rudell (Eds.), Theoretical models and process of reading (pp. 497-508). Newark, DE: International Reading Association.

Grabe, W. (2009). Reading in a second language: Moving from theory to practice. Cambridge: Cambridge University Press.

Halpern, D. F. (2000). Sex differences in cognitive abilities (3rd ed.). London: Lawrence Erlbaum Associates, Inc.

$\mathrm{Hu}$, R. (2009). English reading instruction in elementary schools in China. Reading Matrix: An International Online Journal, 9(2), $150-165$. 
Hudson, T. (1982). The effects of induced schemata on the 'short circuit' in L2 reading: Non decoding factors in L2 reading performance. Language Learning, 32(1), 1-33.

Jalilehvand, M., \& Samuel, M. (2014). Content familiarity and gender-neutral texts in foreign language reading comprehension. Malaysian Online Journal of Educational Sciences, 2(3), 1-21.

Johnston, R. S., Watson, J. E., \& Logan, S. (2009). Enhancing word reading, spelling and reading comprehension skills with synthetic phonics teaching: $i$ Studies in Scotland and England. In Contemporary perspectives on reading and spelling, ed. C. Wood and V.Connelly. London: Routledge.

Khan, B. W., \& Inamullah. (2011). A study of lower-order and higher-order questions at secondary level. Asian Social Science, $7(9), 149-157$.

Lin, B. (2019). The professional connotation and teaching strategies of literary reading --- also on the humanistic infiltration of foreign literature teaching. Foreign Language Learning Theory and Practice, 2019(1), 1-8.

Logan, S., \& Johnston, R. S. (2009). Gender differences in reading ability and attitudes: Examining where these differences lie. Journal of Research in Reading, 32(2), 199-214. Available at: https://doi.org/10.1111/j.1467-9817.2008.01389.x.

Logan, S., \& Johnston, R. S. (2010). Investigating gender differences in reading. Educational Review, 62(2), 175-187. Available at: https://doi.org/10.1080/00131911003637006.

Manizheh, A. (2016). Cross-gender comparison of meta-cognitive strategies utilized by omani students in reading comprehension classes. Australia: Australian International Academic Centre.

McVee, M. B., Dunsmore, K., \& Gavelek, J. R. (2005). Schema theory revisited. Review of Educational Research, 75(4), 53 1-566.

Ming Chui, M., \& McBride-Chang, C. (2006). Gender, context, and reading: A comparison of students in 43 countries. Scientific Studies of Reading, $10(4), 331-362$.

Mullis, I. V. S., Martin, M. O., Gonzalez, E. J., \& Kennedy, A. M. (2003). PIRLS 2001 international report: IEA's study of reading literacy achievement in primary schools in 35 countries. Chestnut Hill, MA: Boston College.

Mullis, I. V. S., Martin, M. O., Kennedy, A. M., \& Foy, P. (2007). PIRLS 2006 international report: IEA's progress in international reading literacy study in primary schools in 40 countries. Chestnut Hill, MA: Boston College.

Nair, S. M., Zhang, Y., \& Wider, W. (2019). Analysis of ESL students comprehension of LOTS and HOTS questions according to gender. Humanities and Social Sciences Letters, 7(2), 74-89. Available at: https://doi.org/10.18488/journal.73.2019.72.74.89.

Nourdad, N., Masoudi, S., \& Rahimali, P. (2018). The effect of higher order thinking skill instruction on EFL reading ability. International Journal of Applied Linguistics \& English Literature, 7(3), 231. Available at: https://doi.org/10.7575/aiac.ijalel.v.7n.3p.231.

Nunan, D. (1991). Language teaching methodologies. Wiltshire: Prentice Hall International.

Oakhill, J. V., \& Petrides, A. (2007). Sex differences in the effects of interest on boys' and girls' reading comprehension. British Journal of Psychology, 98(2), 223-235. Available at: https://doi.org/10.1348/000712606x117649.

OECD. (2016). PISA 2015 results: Excellence and equity in education (Vol. I). Paris: PISA, OECD Publishing.

Pae, T. I. (2004). Gender effect on reading comprehension with Korean EFL learners. System, 32(2), 265-281. Available at: https://doi.org/10.1016/j.system.2003.09.009.

Rumelhart, D. E. (1980). Schemata: the building blocks of cognition. In: R.J. Spiro et al. (eds) Theoretical Issues in Reading Comprehension. Hillsdale, NJ: Lawrence Erlbaum.

Saidi, A. A. (2012). The influence of gender on omani college students' english language learning strategies, comprehension and motivation. International Journal of Applied Linguistics ËEnglish Literature, 4(1), 230- 244. Available at: https://doi.org/10.7575/ijalel.v.1n.4p.230.

Seyedjamal, A. (2014). Gender differences and EFL reading comprehension:Revisiting topic interest and test performance. System, 42, 70-80. Available at: https://doi.org/10.1016/j.system.2013.11.008.

Wang, J., \& Guthrie, J. T. (2004). Modeling the effects of intrinsic motivation, extrinsic motivation, amount of reading, and past reading achievement on text comprehension between US and Chinese students. Reading Research Quarterly, 39(2), 162-186. Available at: https://doi.org/10.1598/rrq.39.2.2.

Yazdanpanah, K. (2007). The effect of background knowledge and reading comprehension test items on male and female performance. The Reading Matrix, 7(2), 64-80.

Yousef, H., Karimi, L., \& Janfeshan, K. (2014). The relationship between cultural background and reading comprehension. Theory and Practice in Language Studies, 4(4), 707-714. Available at: https://doi.org/10.4304/tpls.4.4.707-714.

Zhenhui, R. (2005). Gender, academic major, and Chinese students' use of language learning strategies: Social and educational perspectives. The Journal of ASIA TEFL, 2(3), 115-138.

Zintz, M. (1978). The reading process: The Teacher and the Learner (pp. 269). Dubuque, Iowa, USA: University of Mexico. WM.C. Brown Company Publishers. 